\title{
Research on The Training Guarantee System Of Professional Degree Graduates Based on "Four-Dimensional Linkage"
}

\author{
Zheng $\mathrm{ZHENG}^{1, \mathrm{a}}$ and Jun $\mathrm{ZHU}^{1, \mathrm{~b}}$ \\ ${ }^{1}$ Henan Polytechinic University ,School of Electrical Engineering and Automation,Jiaozuo,China \\ azhengzh@hpu.edu.cn, bzhujun@hpu.edu.cn \\ *zhujun@hpu.edu.cn
}

\begin{abstract}
Keywords: Professional degree graduates, Professional ability orientation, Four-dimensional linkage, Security system.

Abstract. The graduate of professional degree (specialist master) has gradually become the main body of postgraduate education in our country and plays a vital role in postgraduate education. However, there are still some deficiencies in its cultivation process, and we need to constantly improve its training mode. According to the positioning of professional masters, closely linked to professional skills, analyzing the major problems existing in the current master training, and presenting the "four-dimensional linkage" electric engineering graduate degree training model, in order to cultivate a clear direction for professional development, with High-level and complex application talents to provide a guarantee system for innovation consciousness.
\end{abstract}

\section{Introduction}

The electrical engineering discipline of Henan Polytechnic University began in the 1950s. In 1986 and 1995, it began to train and train masters and doctoral students respectively. In 2001, it was approved as a master's degree in the second-level disciplines. In 2012, it was awarded the first-level discipline master degree. The full-time master of electrical engineering graduates began enrollment in 2010. The number of applicants and enrollment continued to increase rapidly. The level of postgraduate education continued to increase, and a large number of high-level applied electrical disciplines for the construction of the Central Plains Economic Zone and the national power grid sector and the coal industry were trained talent. At present, the number of postgraduates of electrical engineering degrees in our school is close to 200, and the ratio between the number of postgraduates and academic graduate students is as high as 1.3:1. Professional degree education has become an important part of postgraduate education, but in the course of training, there are The cultivation system and management mechanism, the tutor's cultivation concept of the students and other aspects are not much different from the academic graduate students, resulting in a certain gap between the professionalism and the personalization training requirements of professional graduate students. Therefore, we will explore the model for cultivating innovative talents for electrical engineering majors that meet our school's characteristics, cultivate multi-level, applied talents, and further improve the quality of postgraduate education to better serve local economic development, especially the construction of the Central Plains Economic Zone, and the power system. And the economic development of the mining industry provides strong support.

\section{Professional Graduate Education Reform Measures and Effectiveness}

\subsection{Based on the Cultivation of Professional Ability, Deepen the Reform of Training Mode, and Improve the Training System}

Fully investigate the training programs for graduates of electrical engineering majors in universities and colleges, and combine the distinctive characteristics of our university's geoscience disciplines, invite relevant corporate mentors to participate in the accurate positioning of professional graduate student training goals, according to the power system and related enterprises to electric engineering students The needs of professional skills consolidate the 4 major professional orientations of 2 major training modules, focusing on the intelligentization of power systems and new energy 
generation, intelligent power supply for coal mines, special motor drive control, power conversion and electrical transmission, and the characteristics of ground-based electrical engineering are distinctive. Training system.

In the formulation of training programs, based on the needs of the electrical industry and coal mining enterprises, the practicality, flexibility and cutting-edge of the curriculum are reflected. The similar curriculum module system is set according to the research direction, highlighting the differences and pertinence of different research direction modules. This allows students to clearly identify learning objectives and employment orientation before choosing. The postgraduate of electrical engineering degree is positioned to enable students to select the corresponding curriculum system according to their professional wishes when formulating personal training plans.

The establishment of a system of responsible persons for the course group will be carried out in an all-round manner. The teaching methods of the "one-student and multiple-professional" curriculum group will be carried out in a comprehensive manner; the engineering concept will be intensified, and the specialized elective courses will be based on the "case study" teaching model. Professional degree courses as the professional basic courses of the professional can lay a solid professional foundation for students. Based on the content of professional basic courses, several senior tutors form a curriculum group, establish the system of responsible persons for the curriculum group, take charge of the curriculum system, curriculum reform, and case library construction. Give full play to the depth and breadth of a teacher's knowledge, and impart the highest quality professional knowledge to students so as to reinforce their professional knowledge. Construct excellent courses such as "modern power change technology" and "power system operation and control", and build case libraries such as "new energy equipment power generation technology" and "DSP control technology and application" to give wind power generation and solar energy in the form of engineering cases. Professional knowledge such as power generation, smart microgrid, and electrical engineering information processing enables students to clearly grasp professional skills in these areas.

The introduction of relevant elective courses in vocational qualification examinations to fully enhance the students' professional skills, focusing on cultivating students' professional technical skills; effectively introducing the enterprise participation training mechanism, solidly promoting innovative "school-industry-enterprise synergistic education" model, and fostering High-quality comprehensive application talents improve the competitiveness of students' employment. In the course system setting, it embodies the core position of professional and practical courses and emphasizes the systematicness of professional competence. For example, the "China Electric Power and Energy Strategy Series Lecture", "Electrical Engineer Knowledge Series Lecture", and "Operation of Coal Mine Power Supply System" are added. The elective courses such as "Maintenance Series Lectures" and "State Grid Examination Series Lectures" will be targeted.

\subsection{Strengthen the Professional Training and Practice Base in and out of the School, and Realize the win-win Cooperation Mechanism of School-enterprise "Cooperative Education"}

Practice base is a key place for cultivating the professional skills and professional skills of professional graduates. It not only shoulders the function of student professional practice, but also is the first place to improve the professional tutor level. Schools and enterprises through the "production, study and research" model, and constantly establish and stabilize the function of the practice base, to achieve "co-education".

Strengthen the cooperation with the power sector, mining companies and electrical equipment manufacturing companies, and combine the actual production projects to cultivate the professional graduate degree to solve practical problems. On the one hand, to solve the actual production problems for the enterprise; on the other hand, the graduates of professional degrees are effectively involved in relevant projects, and through the development of a feasible practice plan, personal professional skills are improved during the completion of the project, and the dissertation is condensed. The topic of the thesis was derived from the scientific research projects undertaken by the school and enterprise partners and the project design research projects. Through professional 
practice recognition, professional knowledge is applied to solve specific production problems, and professional competence is cultivated. The dissertation is used as material to achieve a "comprehensive-enterprise-school” win-win situation.

Improve the campus training base management system. In view of the current state-level national electric and electronic demonstration centers and Xuji's coal mine underground smart power supply laboratories and other bases, the base management system was improved, relevant incentive systems and management measures were formulated, and teachers were encouraged to carry out practical training courses at bases and formulate bases. The system is open to students and students are admitted to the base to carry out research activities and other related policies and systems. Emphasize the practical training of professional ability, increase the proportion of professional and practical courses, and increase the training links, cultivate students' understanding of professional issues, form professional thinking and skills, improve students' ability to solve practical problems, and cultivate high Literacy professional skills in electrical engineering graduate students. For example, training courses such as "Design and Training of Glass Ingredients Monitoring System”, "Simulation of Simulated Fully-mechanized Mining Machine System", "Study of FPGA Comprehensive Development System Training", and "Fault Simulation and Wavelet Analysis of Coal Mine Underground Power Grid” were conducted.

Secure the off-campus "production, study and research" practice base. Through the social service of tutors, solve corporate practice problems, establish enterprise practice bases, formulate internship rules and management methods for production, education, and research bases, invest in related base construction costs through cooperation of both parties, and learn from the experience of Jiangsu postgraduate workstations and strive to obtain strong support from the government. To ensure the continuous and stable development of the established and pre-built bases.

The topic of the dissertation is selected from the scientific research projects undertaken by the school and enterprise cooperation units and the project design research topics, serving the professional field. Mainly for the electric field of production in the actual scientific research projects or need to solve the engineering problems, through professional practice, knowledge, application of professional knowledge to solve specific production problems, and use this as a material to write dissertations. For example, the graduate of electrical engineering degree in our school entered Jiaozuo Huafei Electronic Appliance Company to carry out professional practice. After a period of practice, they participated in the "Huafei Cup" science and technology competition. Some of the students finally selected the contest topic, that is, on-site actual projects continue to conduct in-depth research. Graduate degree thesis material. This type of dissertation can not only reflect academic value, but also have application value. It truly embodies the value and significance of scientific research or solves practical problems and application value of engineering design.

\subsection{Constructing a practical teaching system based on professional ability}

Closely centering on the professional training objectives and industry characteristics, with the professional ability as the guide, build a "four-in-one" practical teaching system of "school + enterprise + project + science and technology competition." The practical teaching link runs through the entire training process. The training method is the supervisor responsibility system, and the training method of "curriculum learning + professional practice + dissertation work" is adopted. The three links can be combined to carry out the combination of on-campus classroom teaching and corporate teaching. The company's production site practices are unified, the dissertation adopts the dual-tutor system, the enterprise problem-oriented formation project (the project), the school-enterprise joint guidance to complete the master's degree thesis, the practical teaching system is shown in Table 1. 
Table 1. "Four in One” Practical Teaching System

\begin{tabular}{|c|c|c|c|}
\hline order & $\begin{array}{l}\text { Practice } \\
\text { module }\end{array}$ & Practice content & $\begin{array}{l}\text { Practice } \\
\text { location/form }\end{array}$ \\
\hline 1 & $\begin{array}{l}\text { Professional } \\
\text { skills training }\end{array}$ & $\begin{array}{l}\text { Power System Engineering Design Training } \\
\text { Industrial and mining enterprises electrical control } \\
\text { training } \\
\text { Glass ingredients monitoring system design and } \\
\text { training } \\
\text { Siemens S7-300PLC network monitoring system } \\
\text { design and training } \\
\text { Analysis of Operation Principle of Small Direct } \\
\text { Drive Hoisting System Based on PLC and Frequency } \\
\text { Converter } \\
\text { Multi-freedom direct drive servo platform structure } \\
\text { and operation training } \\
\text { Understanding and Application of Underground } \\
\text { Intelligent Power Supply System in Coal Mines } \\
\text { Fault Simulation and Recorded Wave Analysis and } \\
\text { Training of Mine Underground Power Network } \\
\text { Coal mine underground power grid anti-overclass } \\
\text { trip system training training }\end{array}$ & $\begin{array}{l}\text { School practice } \\
\text { base / project }\end{array}$ \\
\hline 2 & $\begin{array}{l}\text { Business } \\
\text { practice }\end{array}$ & $\begin{array}{l}\text { Power generation equipment, power distribution } \\
\text { equipment, electrical control equipment, design, } \\
\text { manufacturing work } \\
\text { New product new technology research and } \\
\text { development } \\
\text { Generator set centralized operation, equipment } \\
\text { maintenance, maintenance, commissioning } \\
\text { production process management, engineering } \\
\text { technology management or equipment management }\end{array}$ & $\begin{array}{l}\text { Off-campus } \\
\text { practice } \\
\text { base/practice }\end{array}$ \\
\hline 3 & $\begin{array}{l}\text { Scientific } \\
\text { research }\end{array}$ & $\begin{array}{l}\text { Participate in mentoring and corporate research } \\
\text { classes, write technical papers, project applications, } \\
\text { final reports and other technical documents }\end{array}$ & $\begin{array}{l}\text { School, } \\
\text { company/proje } \\
\text { ct }\end{array}$ \\
\hline 4 & $\begin{array}{l}\text { Extracurricul } \\
\text { ar } \\
\text { Technology } \\
\text { Competition }\end{array}$ & $\begin{array}{l}\text { Graduate Electronic Design Competition } \\
\text { Siemens China Smart Manufacturing Challenge } \\
\text { "Hua Fei Cup" Competition (Hua Fei Sponsored } \\
\text { Competition Scholarship) } \\
\text { College Students Innovation and Entrepreneurship } \\
\text { Challenge Cup }\end{array}$ & $\begin{array}{l}\text { Campus } \\
\text { Innovation } \\
\text { Base / Contest }\end{array}$ \\
\hline
\end{tabular}

2.4 Granting Professional Skills in Science and Technology Competitions to Cultivate Students' Scientific and Technological Innovation Abilities to Improve Student Professional Skills with Competitions

Formulate incentive incentive policies for science and technology competitions to offset professional training credits at the level of winning competitions, so as to increase students' initiative in participating in events and ensure the smooth flow of professional and professional skills. Encourage graduate students to participate in postgraduate electronic design competition, Siemens China Intelligent Manufacturing Challenge, "Huafei Cup" competition (Hua Fei sponsored competition scholarship), college students innovation and entrepreneurship competition, challenge cup and other events. In order to enable students to fully access and profoundly grasp the basic knowledge and professional technical skills associated with the electrical profession, broaden the 
students' innovative thinking, enhance professional skills and innovation in the competition, so that students' professional and technical skills are further sublimated.

\subsection{Improve the Management System of Professional Master Degree Graduates, Strengthen Supervision and Management of Postgraduate Training Process}

Under the overall management of the graduate work office, the college is equipped with a professional graduate manager alone.Employees, effectively strengthen the supervision and management of the graduate training process, and formulate corresponding rules and regulations, incentive policies, and evaluation mechanisms to ensure that all aspects of the program follow the project's professional degree training standards. For example, when the topic is opened, the subject orientation should be organized for the team. The team leader must give an opinion on whether to approve the opening question according to the opening question, and finally submit the opening and professional match report so as to avoid the deviation of the research content from the professional direction. Wait.

Strengthen the training of "dual-qualified" tutors and enhance the awareness of tutors of the first responsible person. We will vigorously promote the practice of new young teachers in the field, gradually increase the number of "dual-qualified" tutors, and continuously improve the professional engineering level of postgraduate tutors, and in particular, enhance tutors' professional guidance skills and strengthen the awareness of tutors as the first responsible person. At the same time, the tutor not only needs to impart the academic theory and professional skills of graduate students, but also needs to correctly guide the character of graduate students. Strengthen the construction of teachers' morality, improve the instructor's powers and responsibilities, take up positions and exit mechanisms, and improve the mechanism for the first person responsible for the tutor.

The optimization of the evaluation mechanism and the smooth implementation of the reform must rely on the support and supervision of the policy system. The establishment of a series of evaluation mechanisms such as management and incentives is the key to ensure the smooth implementation of all tasks of the project. Combine the documentary policies issued by the school, optimize the evaluation mechanism, formulate the "Details of Practice and Management of Production, Teaching, and Research Bases" of the School of Electrical Engineering, and revise the "selection system for professional graduate student tutors", formulate the "Management System for Multi-Course Curriculum Group Management," and formulate "Young teachers' on-site training system, "graduate scholarship selection and management methods" and other related documents to ensure the protection system.

\section{Summary}

This article takes the cultivation of professional skills and professional skills of postgraduates of electrical engineering degree as a guide, integrates vocational qualification training or examination courses into the training program with the elective mode, and innovatively introduces science and technology competitions into the training process. 1 Construct a quality assurance system for diversified electric engineering majors in a four-dimensional linkage based on "rebuilding the training system, solidifying a platform for innovation and practice, and adopting a competition-based learning model, and optimizing the evaluation mechanism"; 2 lead by the concept of synergistic education and give full play to our school Advantages of running schools, building a "four-in-one" practical teaching system of "school + enterprise + project + science and technology competition". Develop high-level, multi-disciplinary talents with clear and professional awareness in career development.

\section{Acknowledgement}

This research was financially supported by the Higher Education Teaching Reform Ressearch and Practice in Henan province(2017SJGLX033Y), Professional Degree Graduate Education Comprehensive Reform in Henan Polytechnic University(2016YZG03), Postgraduate Case 
Database Course Construction(2017YAL03， 2016YAL11).

\section{References}

[1] Huang Qian.The research on the transformation of the personnel training moda of pedagogy undergraduate[D].Shen yang normal university,2016

[2] Yang Qing.Enlightenment of MBA case database construction to that of international chinese teaching[J].Journal of research on education for ethnic minorities.2013,24(5),88-93

[3] Peng Xu.Study on cooperation mode of production,teaching and research in local university from the perspective of practical talents[J]. Science and technology management research.2010,13,143-145

[4] Zhao Shilu,Wang Shuang, Liu Shuang,et al.Production-study-research collaboration innovation mode: taking matal material engineering major in Shenyang university as an example.Journal of Shenyang university(social science).2018,20(1):14-23

[5] Jiang Wei,Jin Zhongcao,Jiang Jiansheng.“Four in one integrity”practical teaching and training of innovation and entrepreneur ability of undergraduates.Journal of anqing teachers college(natural science edition).2016,22(1):134-137 